\title{
ANALISIS GENETICO DE DIVERSAS CARACTERISTICAS REPRODUCTIVAS EN EL CONEJO DE CARNE
}

F. GARCIA, A. BLASCO, M. BASEI,GA y A. SALVADOR

Departamento de Genética de la Escuela Técnica Superior de Ingenieros Agrónomos,
Av. Blasco Ibánez, 2 , Valencia

En dos líneas de producción de carne, NZ (origen neozelandés blanco) y CA (origen principal californiano), se estudian desde el punto de vista genético los siguientes caracteres : Número de conejos nacidos vivos por camada, tamaño de la camada al destete, número de conejos quel lega al sacrificio por camada -a los 28 y 77 dias de vida respectivamente-, y pesos de la camada al destete y sacrificio.

El estudio incluye, separadamente por cada línea, el cálculo de las medias, desviaciones típicas, y correlaciones fenotípicas. Se estiman ađemás las correlaciones intraclase vía padre y vía madre y la regresión intrapadre madre-descenđencia, tanto cuando los caracteres se consideran como maternos como cuando se consideran como de los productos. Los resultados se discuten en función de las componentes de la varianza genética y ambiental atribuible a la madre y a los productos, $y$ en función de las covarianzas entre ellos.

\section{EVALUACION DE LA HETEROSIS, DE IA CAPACIDAD DE COMBINACIÓN Y DE LOS EFEC TOS MATERNOS $\mathrm{X}$ RECÍPROCOS EN CONFJOS}

\section{R. D. CARREGAI,}

Faculdade de Ciências Agrárias e Veterinarias "Campus " de Jaboticábal Departamento de Produção Animal, Rodovia Carlos Tonanni $\mathrm{km} 5$ Jaboticabal, São Paulo, Brasil

An experiment in complet diallel design was conducted with four different breeds of rabbitsDutch, New Zealand White, Californian and Bouscat Giant.

The data obtained from 64 litters at birth, 28 and 70 days of age, in a total of 326 offspring, born from 64 dams and 32 sires, were analyzed.

Heterosis, general and specific combining abilities, maternal effects and reciprocals were analyzed in terms of their effects on weight at birth, weaning and slaughter.

Litter size affected the weights at birth, weaning and slaughter, while the month of tirth affected only the weights at birth and weaning. at birth.

The estimate of hibrid vigour showed from 6.5 to I 5 p. Ioo of superiority of the crossbreds

The best performance among the purebred animals was that of the Bouscat Giant rabbits which also showed general combining ability for weight at weaning and slaughter.

The maternal effect of the Dutch dams negatively affected litter development.

The reciprocal effects clearly showed that only the males of some breeds can be used to increase rabbit weight at weaning and slaughter.

\section{INFLUENCE DE LA VARIATION DU TAUX CONSANGUINITÉ, SUR LES PERFORMANCES D'ÉLEVAGE, DE I APINES UTIIISÉES EN CROISEMEN'T DE SOUCHES}

\section{B. POUJARDIEU et S. TOURÉ}

\author{
Station d'Amélioration génétique des Animaux \\ I.N.R.A., Toulouse, \\ B.P. I2, 3тз2о Castanet Tolosan
}

Nous avons apprécié, en étudiant les performances de 325 mises-bas de 94 lapines de petit format, de deux souches consanguines, ayant produit en rythme semi-intensif (saillies Io jours après mise-bas) pendant 6 mois en croisement de souches, l'influence de l'augmentation du taux de consanguinité de la mère sur sa productivité numérique en croisement et sur la croissance 
jusqu'au sevrage des lapereaux. Une augmentation de to p. Ioo du taux de consanguinité entraîne une diminution de 0.17 lapereaux à la naissance, 0.37 au sevrage et une diminution de I $6 \mathrm{~g}$ de poids moyen du lapereau au sevrage. Cette influence depressive est la plus marquée au sevrage moment où le lapereau résume toutes les influences auxquelles il a été soumis depuis le stade foetal. Nous montrons que les qualités maternelles des lapines sont affectées par l'augmentation de leur taux de consanguinité.

\title{
MÖGLICHKEIT VON KURZENTESTE BEI DER SELEKTION DER KANINCHEN
}

A. SUSHKA und S. HOLDAS

\section{Research Institute for small Animals Gödölló, Ungarn}

The feasibility of short tests concerning number of litters and living weight at the age of $2 \mathrm{I}$ days was studied in the New Zealand White and California breeds in two respectively closed lines. The tests included indications on mothers with ten or more litters that had reached the age of $2 \mathrm{I}$ days. The results of Io litters were considered to be the performance of a life cycle. The results of the first, first and second, first, second and third litter etc,... were correlate and compared to life cycle performance. With respect to these two properties it could be seen that the results of the first three litters can certainly be used as basis for forecasting total life cycle performance. The results of the first three litters can there fore be used for selection and can accelerate significantly genetic progress.

\section{EXPÉRIMENTATION EN SÉLECTION SUR IA VITESSE DE CROISSANCE DU LAPIN RÉSULTATSS PRÉLIMINAIRES}

\author{
R. ROUVIER, F. TUDELA, R. DUZERT
}

\author{
Station d'amélioration génétique des animaux, \\ I.N.R.A., Toulouse, \\ B.P. I2, 3т32o Castanet Tolosan (France)
}

A partir de I975, une expérimentation en sélection sur la vitesse de croissance pondérale entre 30 jours (sevrage) et 77 jours (âge d'abattage) des lapereaux a été entreprise. Ia méthode est une sélection massale, dans les deux sexes, sur les lapereaux issus des premières portées, de façon à maximiser le progrès génétique par unité de temps. La génération initiale (GO) est la $4^{\mathrm{e}}$ génération de constitution d'une souche synthétique réalisée par J. OUHAyouN. A partir des lapereaux de la GO, l'on a constitué un lot de sélection et un lot témoin maintenu sans sélection. L'effectif de reproducteurs de la souche sélectionnée est de $\mathrm{I} 2 \widehat{\delta} \times 60$ \% mis en reproduction

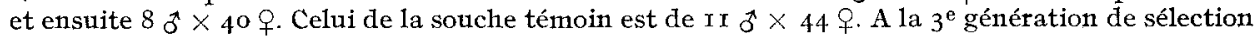
à partir de GO, le gain génétique obtenu sur la vitesse de croissance journalière moyenne est $\mathrm{de}+2,6 \mathrm{~g} / \mathrm{j}$, ce qui correspond à une héritabilité réalisée $\mathrm{h}^{2}=0, \mathrm{I} 8$. Le gain génétique sur le poids individuel à 77 jours est de + Ioo $\mathrm{g}$. Il ne semble pas y avoir de réponse corrélée importante sur les autres caractères analysés, notamment les tailles de portée. Ces résultats sont préliminaires. L'analyse doit être plus approfondie (possibilités d'interaction génotype $\times$ milieu) et porter sur un plus grand nombre de générations (plus grande précision de la réponse à la sélectioñ).

\section{POSSIBIIITY AND ADVANTAGE OF INDIRECT SELECTION FOR IMPROVING FEED CONVERSION IN YOUNG RABBITS}

\section{Z. SZENDRÖ}

\section{Research Institute for small Animals Gödölló, Hungary}

The effect of weight gains and live weight on feed conversion rates in young rabbits between the ages 7-II weeks was studied by the author. According to his findings, there is a strong, but inverse relationship between the two properties and feed conversion $/ v_{p}=-0,83 ., 0,75 /$. The regression relationship between the three properties is:

$$
Y=-0,0028 I X_{1}+0,001 I 3 X_{2}+3,134
$$

